\title{
THE SPECIES OF METOPOGRAPSUS (CRUSTACEA, BRACHYURA)
}

\author{
BY \\ M. W. F. TWEEDIE, M.A.
}

The most recent comprehensive treatment of this Indo-Pacific genus ${ }^{1}$ ) is that of TESCH (1918, p. 78-82). Here seven species are recognised with the reservation that $M$. eydouxi $\mathrm{H}$. Milne Edwards and $M$. thukuhar (Owen) are possibly not distinct.

In 1936 (TwEedie 1936, p. 49) I questioned the validity of the character used to separate $M$. latifrons (White) and $M$. maculatus H. M.-E., the relation of carapace length and breadth, and placed maculatus in the synonymy of latifrons.

In 1947 I examined the series of Metopograpsus in the collections of the British Museum, the Rijksmuseum van Natuurlijke Historie at Leiden and the Zoologische Museum at Amsterdam, paying particular attention to the first pleopods of the male. Six very distinct types of pleopod were found, and on this basis six species are recognised.

In figuring the first male pleopod, the right hand pleopod is drawn in every case, and in all except two it is placed resting on the outer abdominal facet with the distal end upwards and the chitinous projection pointing upwards to the right (see TwEEDIE I940, p. 89), as this position best displays the characters of the projection. The pleopod of $M$. messor, however, displays its characters better from the opposite side, i.e. resting on the sternal surface, and has been drawn in this position (fig. I $e$ ) together with the smaller scale figure of that of $M$. gracilipes (fig. I $g$ ) with which messor has been long confused.

I) The condition of the inner orbital lobe, whether or not it touches the front, and so excludes the antenna from the orbit, does not satisfactorily separate the species traditionally included in Metopograpsus from those of Pachygrapsus. TESCH (1918, p. 78) draws attention to this, and the fact is that in two species, thukuhar and quadridentatus, there is usually a distinct gap between the orbital lobe and the front. For the present, however, I have retained these two in Metopograpsus and have concerned myself in this paper only with the discrimination of the species included in this genus by DE MAN (1888, p. 359) and Tesch (1918, p. 78). 

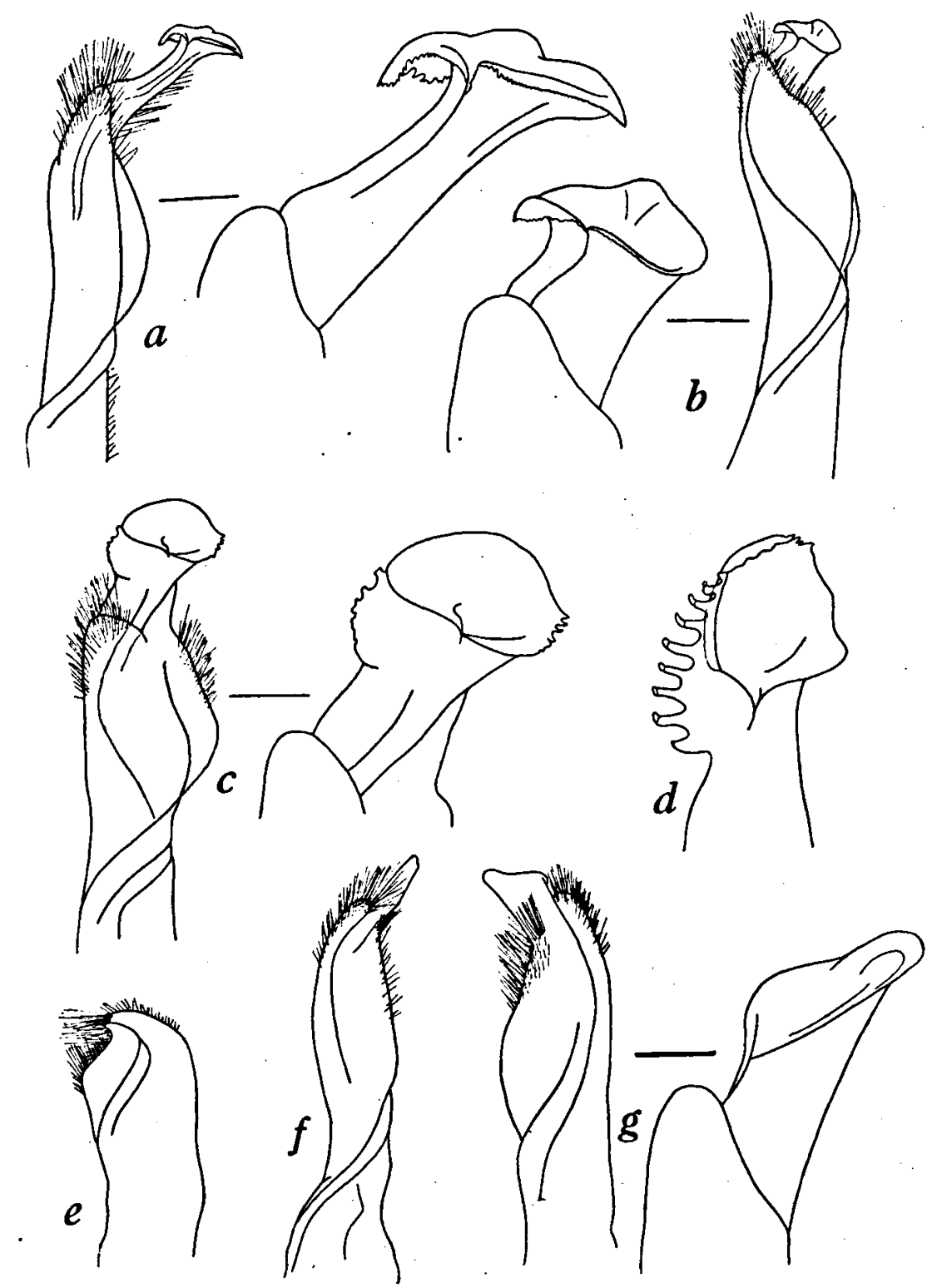

Fig. I. Male first pleopods of Metopograpsus spp. a. M. latifrons (Singapore): b. M. oceanicus (Singapore); c. M. quadridentatus (Amoy); d. M. quadridentatus (Merauke, New Guinea); e. M. messor (Djeddah); f. M. thukuhar (Cocos Keeling Islands); $g$. M. gracilipes (Singapore). 
My thanks are due to the Directorates of the three Museums in which I examined material, and to Miss Alida M. Buitendijk, Mrs. W. S. S. van Der Feen and Dr. Isabella Gordon, who spent a great deal of time and trouble in helping me at Leiden, Amsterdam and London respectively. Dr. GoRDon also greatly assisted me by examining the types of $M$. intermedius H. Milne-Edwards in the Paris Museum.

Metopograpsus latifrons (White). Fig. I $a$.

H. Milne-EdWARds, I853 p. I65 (M. maculatus).

A. Milne-Eddwards, 1867 , p. 283 (M. pictus).

Tesch, I9I8, p. 80, 81 (M. latifrons and M. maculatus).

TWEedie, 1936, p. 48.

All male specimens identified under the three names in the above synonymy were found to have the chitinous projection of the first pleopod of the peculiar form illustrated in fig. I $a$.

This confirms the correctness of Tesch's action in uniting pictus, and of my own in uniting maculatus, with latifrons. Evidently the proportions of the carapace are variable.

Metopograpsus oceanicus (Jacq. et Lucas). Fig. I $b$.

TESCH, I9I8, p. 8I.

This is, perhaps, the most abundant species. It certainly is so in the neighbourhood of Singapore.

Metopograpsus quadridentatus Stimpson. Fig. I $c, d$.

TESCH, I9I8, p. 79.

TweEdie, 1936, p. 48 (Pachygrapsus quadratus).

This is one of the species in which the morphology of the antennal region is not distinct from that of Pachygrapsus. This led me to redescribe the species in 1936 , and I suspect that the form recorded by LANCHESTER as $P$. transversus (LANCHESTER, 1900, p. 755) was really $M$. quadridentatus, and that this mistake led him to suggest that $P$. transversus is a variety of $M$. oceanicus. As Tesch points out (I9I8 p. 82), the true $P$. transversus cannot possibly be confused with $M$. oceanicus, but the latter species and $M$. quadridentatus are by no means easy to distinguish.

One male specimen of quadridentatus in the Amsterdam Museum, collected in 1905 at Merauke, New Guinea, is unusual in some of its characters. It is very large, having the anterior carapace breadth $28 \mathrm{~mm}$., and both the abdominal segments and the first pleopod differ from those of normal specimens. The distal abdominal segments are relatively broader than usual, as the following table shows: 


$\begin{array}{lcc} & \begin{array}{c}\text { Merauke } \\ \text { acb } 28 \mathrm{~mm} .\end{array} & \begin{array}{c}\text { Singapor } \\ \text { acb 22 mm }\end{array} \\ \text { Abd. segment 6 } & & \\ \text { a. basal breadth } & 9.5 & 6.6 \\ \text { b. length } & 3.5 & 3 . \\ \text { a/b } & 2.7 & 2.2 \\ \text { Abd. segment 7 } & 7 & \\ \text { a. basal breadth } & 4.4 & 4.3 \\ \text { b. length } & I .6 & 3.2 \\ \text { a/b } & & I .35\end{array}$

The normal first pleopod is shown in fig. I $c$ and that of the Merauke specimen in $d$. It is possible to regard $d$ as a development of $c$ by a change in proportions and hypertrophy of the characteristic truncate teeth, and $I$ regard this difference and that of the abdominal segments as gerontic characters, with the reservation that if they are found also in smaller specimens, without gradation towards the normal characters of quadridentatus, a new species may have to be established.

Metopograpsus thukuhar (Owen). Fig. I $f$.

H. Milne-Edwards, I853, p. I65 (M. eydouxi).

Tesch, I9I8, p. 80.

The morphology of the antennal region is developed as in $M$. quadridentatus. The simple, finger-shaped chitinous projection of the male first pleopod is distinctive.

Records seem to indicate that the species has a predeliction for oceanic islands. OrTmann's suggestion that it does not inhabit the Indian Ocean is incorrect; specimens from the Cocos Keeling Islands are in the collection of the Raffles Museum.

Metopograpsus messor (Forskål). Fig. I $e$.

Tesch, I9I8, p. 79 ( $M$. messor, part).

STEPHENSEN, IO45, p. I95.

In its gross characters this species closely resembles the next ( $M$. gracilipes), but the very peculiar male first pleopod leaves no doubt that the two are specifically distinct. This short, thick pleopod with no obvious chitinous projection (fig. I $e$ and Stephensen, 1.c.) is quite unlike that of any of the other species, and, if taken by itself, would suggest a generic distinction. Obviously this does not exist, and the case affords a warning against the use of this character in classification as opposed to discrimination of species.

The propodites of the legs are slightly broader in messor than in gracilipes (rinte infra) and the chelae in messor are always a rich chestnut brown. This. colour is apparent even in old spirit specimens and is the most obvious character distinguishing the two species.

All the specimens of messor I examined were from the Red Sea and Persian Gulf. 
Metopograpsus gracilipes De Man. Fig. I $g$.

DE MAN, 1891, p. 49; 1895, p. 75 (M. messor var. gracilipes).

TEsch, 1918, p. 79 (M. messor subsp. gracilipes) and p. 80 under $M$. thukuhar. "the genuine $M$. messor").

The similarity of this species to $M$. messor has already been mentioned and they have long been regarded as identical, only few authors having followed DE MAN in regarding them as even varietally or subspecifically distinct. But the evidence of the male first pleopod (fig. $I e$ and $g$ ), which could hardly be more dissimilar, shows that DE MAN was right (as he usually was) in distinguishing the two, and it gives me pleasure to confirm his opinion.

DE MAN distinguished gracilipes by the more slender propodites of the walking legs. The colour of the chelae also differs, being pale in gracilipes and deep chestnut brown in messor. The latter species seems to be confined to the Arabian and East African area, while gracilipes inhabits the Pacific Ocean and Indo-Australian Archipelago; how far it extends into the Indian Ocean cannot yet be determined.

De MAN (I888 p. 359) stated that M. intermedius Milne-Edwards is without doubt identical with $M$. messor. Thinking that intermedius might have been founded on DE MAN's var. gracilipes rather than on typical messor, and therefore be the valid name for this form, I asked Dr. I. Gordon of the British Museum, who was fortunately about to visit Paris, to examine the type. She found that two cotypes had been designated, a large and a smaller male, so she sent me sketches of the pleopods of each. These show very clearly that the large "cotype" is indeed DE MAN's gracilipes, but the other is undoubtedly $M$. thukuhar! The name intermedius is therefore composite and cannot be used.

The following key will now serve to distinguish the species.

I. Lateral borders of the carapace entire .

- A tooth on the lateral border behind the external orbital angle

2. Front very prominent: sides of carapace strongly convergent backwards; propodus of 3 rd walking leg more than twice as long as dactylus; first male pleopod as in fig. I a. . . . . . . . . . M. latifrons.

- Front less prominent; sides of carapace less convergent backwards; propo-

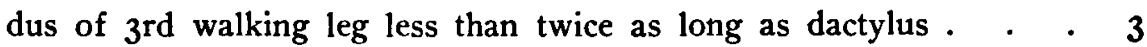

3. Inner orbital lobe sharp and strongly keeled, and extensively fused with the front; sides of carapace distinctly convergent backwards . . . 4

- Inner orbital lobe blunt, not or weakly keeled, and not extensively fused with the front; sides of carapace scarcely convergent backwards; first male pleopod as in fig. I $f$. . . . . . . . . M. thukuhar

4. Propodite of $3^{\text {nd }}$ walking leg about twice as long as broad; chelae deep chestnut colour; first male pleopod as in fig. I $e$. . . . . M. messor

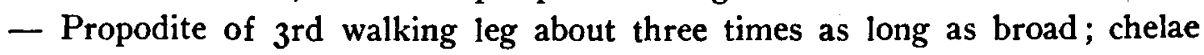
whitish; first male pleopod as in fig. I $g . \ldots$. . . . M. gracilipes 
5. Cervical groove deep and continuous, appearing like an arc of a circle; inner orbital lobe keeled, pointed and extensively fused with the front; propodites of all but last pair of walking legs with a linear fringe of fine hairs on the upper surface; first male p!eopod as in fig. I b. M. oceanicus

- Cervical groove shallow and discontinuous; inner orbital lobe not keeled and not extensively fused with the front; propodites without such a fringe of hairs; first male pleopod as in fig. $\mathrm{I} c$ (or $d){ }^{\bullet} . . M$, quadridentatus

\section{LITERATURE}

De Man, J. G., I888. Bericht über die im indischen Archipel von Dr. J. Brock gesammelten Decapoden und Stomatopoden (Arch. für Naturgeschichte, 53, pp. 215-600).

—, 1895. Bericht über die von Herrn Schiffscapitän Storm...... gesammelten Decapoden und Stomatopoden (Zoologische Jahrbücher, Abt. für Systematik, 9, pp. 75-218).

LANCHESTER, F. W., 1900. On a collection of Crustacea made at Singapore and Malacca (Proc. Zool. Soc., London 1900, pp. 719-770).

Milne-Edwards, A., 1867. Description de quelques espèces nouvelles des Crustacés Brachyures (Ann. Soc. Entomol. France, (4) tom. 7, pp. 263-288).

Milne-Edwards, H., I853. Mémoire sur le famile des Ocypodiens (Ann. Sci. Nat. Zool. (3), tom. 20).

Stephensen, K., I945. The Brachyura of the Iranian Gulf (Danish Scientific Investigations in Iran, part 4, pp. 57-237).

Tesch, J. J., I918. The Decapoda Brachyura of the Siboga Expedition, I (Siboga Monograph 39 c, 148 pp.).

TWEEDIE, M. W. F., I936. On the crabs of the family Grapsidae in the collection of the Raffles Museum (Bull. Raffles Mus., 12, pp. 44-70).

-, r940. New and interesting Malaysian species of Sesarma and Utica (Bull. Raffles Mus., 16, pp. 88-113). 